This item was submitted to Loughborough's Research Repository by the author.

Items in Figshare are protected by copyright, with all rights reserved, unless otherwise indicated.

\title{
Perspectives of UK housebuilders on the use of offsite modern methods of construction
}

PLEASE CITE THE PUBLISHED VERSION

PUBLISHER

(c) Taylor \& Francis

VERSION

AM (Accepted Manuscript)

LICENCE

CC BY-NC-ND 4.0

\section{REPOSITORY RECORD}

Pan, Wei, Alistair G.F. Gibb, and Andrew R.J. Dainty. 2019. "Perspectives of UK Housebuilders on the Use of Offsite Modern Methods of Construction". figshare. https://hdl.handle.net/2134/6244. 
This item was submitted to Loughborough's Institutional Repository (https://dspace.lboro.ac.uk/) by the author and is made available under the following Creative Commons Licence conditions.

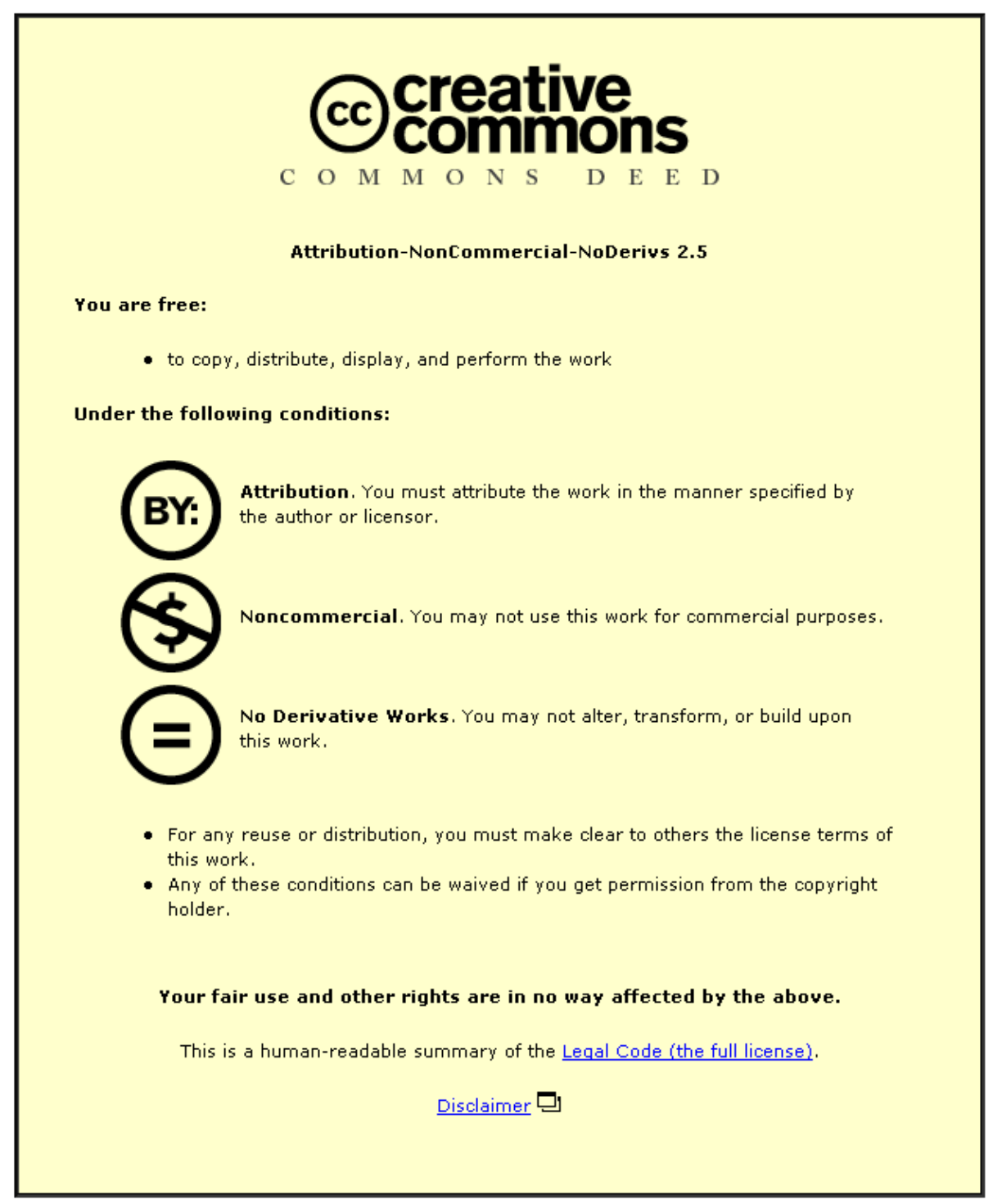

For the full text of this licence, please go to: http://creativecommons.org/licenses/by-nc-nd/2.5/ 


\title{
Perspectives of UK housebuilders on the use of offsite modern methods of construction
}

\author{
Wei Pan, Alistair G. F. Gibb and Andrew R. J. Dainty \\ W.Pan@lboro.ac.uk, A.G.Gibb@lboro.ac.uk and A.R.J.Dainty@lboro.ac.uk \\ Department of Civil and Building Engineering, Loughborough University, \\ Loughborough, LE11 3TU, UK
}

\begin{abstract}
Despite an increasing demand for housing and wider concerns over the need to improve performance, the industry seems to be reluctant to adopt offsite technologies. Many studies have attempted to scrutinize the barriers and seek ways forward, but the perspectives of housebuilders remain unclear. This research aims to investigate UK housebuilders' views on the use of offsite Modern Methods of Construction (offsite-MMC). This was carried out through a combination of personal interviews and a questionnaire survey of the top 100 housebuilders by unit completion. Results suggest that the traditional drivers of time, cost, quality and productivity are still driving the industry in deciding whether to use offsite technologies. Nearly two thirds of the firms believed that there needs to be an increase in the take-up of such technologies. However, current barriers relate to a perceived higher capital cost, complex interfacing, long lead-in time and delayed planning process. Strategies recommended centred on changing peoples' perceptions, improving procurement, providing better cost data, tackling planning and regulations, encouraging political levers and providing practical guidance. The suggestions present a model for encouraging the take-up of offsite-MMC in the future.
\end{abstract}

Keywords: Housebuilding, offsite-Modern Methods of Construction (offsite-MMC), offsite production, perspective, strategy.

\section{Please cite this paper as:}

Pan, W., Gibb, A.G.F. and Dainty, A.R.J. (2007) Perspectives of UK housebuilders on the use of offsite modern methods of construction. Construction Management and Economics, 25(2), 183-194. 


\section{Introduction}

Since the 1960s the number of UK housing completions has been on a downward trend, but, at the same time, there has been a significant rise in the number of households (ODPM, 2005a). The number of households is forecast to increase by 3.8 million between 1996 and 2021, equivalent to around 150,000 each year (DETR, 2000). Recent statistics even show that there will be 39,000 more new households formed in the UK each year than was previously thought, up from the estimate of 150,000, which was based on 1996 statistics (Barker, 2003; ODPM, 2005a). Given the demand for housing in the UK, concerns abound as to the whether traditional methods are able to meet housing demand and quality standards (Housing Forum, 2002; Barker, 2003; ODPM, 2003). Barker warned that the under-supply of housing is constraining economic growth and prosperity. The housebuilding industry is therefore facing great challenges in seeking alternative ways to deliver housing in productivity and quality.

The Barker Review (2003) suggested that offsite technologies could both improve the quality of construction and address skills constraints in the industry. Modern Methods of Construction (MMC) is the term used by the UK Government to describe a number of innovations in housebuilding, most of which are offsite technologies, moving work from the construction site to the factory (Gibb, 1999). Offsite technologies offer potential for reductions in cost, time, defects, health and safety risks and environmental impact and a consequent increase in predictability, whole life performance and profits (e.g. Sparksman et al., 1999; Gibb, 1999; Housing Forum, 2002; Parry et al., 2003; Venables et al., 2004; Buildoffsite, 2005). However, 
both the nature and the scale of innovation in the UK housebuilding industry are very conservative in comparison with other countries (Hooper, 1998). 'Traditional' UK housebuilding technologies comprise brick / concrete block cavity wall methods. Most traditional low-rise, individual houses in the UK are built using brick / concrete block walls with timber or precast floors and timber truss roofs. Traditional mediumrise apartment blocks tend to be considered with steel or in situ concrete frames and in situ brick cladding. The industry has been shown to be slow to adopt innovative building technologies (Ball, 1999; Barlow, 1999; Roskrow, 2004). Concerns with housing built by MMC exist in a wide range of industry players (POST, 2003). A recent buildoffsite survey (Goodier and Gibb, 2005) identifies that the proportion of the UK offsite market, when compared with the total value of the UK construction sector, is $2.1 \%$.

The limited take-up of offsite technologies has triggered many industry and research initiatives attempting to scrutinise the barriers and seek ways forward in housing supply. However, even though the perspectives of housebuilders on the use of such technologies have been studied, they remain unclear. This paper aims to investigate the perspectives of housebuilders on the use of offsite technologies. It probes housebuilders' views on the current and future developments of offsite-MMC, explores the driving forces and the inhibiting factors, and discusses their recommendations for a wider take-up of offsite-MMC in the future.

\section{Industry perspectives on the use of offsite-MMC}

Following the reports of Latham (1994) and Egan (1998), many studies have attempted to investigate industry perspectives on the use of offsite technologies. 
Edge et al. (2002) found that house buyers are so strongly influenced by negative perceptions of the post-war 'prefab' that they will resist any innovations in house construction which affect what a 'traditional' house looks like. The human perception barrier, grounded in the historical failure of offsite practices, also exists among architects and other designers (Pan et al., 2004). This, coupled with technical difficulties (e.g. site specifics, logistics, interfacing problems), high costs (where economies of scale are not possible) and the fragmented structure of the supply chain inhibits designers' acceptance of offsite technologies (ibid). Within the social housing sector, Palmer et al. (2003) suggested that architects, contractors / producers, developers, maintenance and implementers had a significant impact on the success of innovative modern manufactured housing schemes due to their contribution to the development process and their role in the decision making process. However, recent research suggests that there was no clear evidence of a relationship between design quality and the use of MMC (Lusby-Taylor et al., 2004). The majority of schemes used MMC for reasons of speed, even though cost savings were expected from using MMC and some reported that projects would cost more than if traditionally built (ibid). Furthermore, other research (BRE Certification, 2005), has identified increasing concerns from the financial market and insurance industry over the use of offsite technologies in housing.

Several government-backed studies have explored enablers and barriers of offsite innovation from a wider range of stakeholders' perspectives. The Housing Forum (2001) examined the barriers to innovation that clients, contractors, housebuilders and developers, consultants and suppliers are confronting on a daily basis in their organisations' working relationships and on site. The study provided 
recommendations around aspects of culture, design and construction, and the regulatory environment and called for efforts from the whole supply chain. The Housing Forum (2002) took a more detailed look at the use of offsite technologies and presented the related implications to a wide range of stakeholders including housebuilders and developers, offsite fabricators, suppliers, surveyors, lenders, insurers and purchasers. However, although these initiatives have provided the industry context of offsite applications, in-depth investigations of housebuilders are still needed.

Venables et al. (2004), drawing on the results of interviews with 27 key players in both manufacturing and housing development, suggested that the uptake of offsite manufacture is partly influenced by the perceptions of developers with regard to its advantages and disadvantages, which are themselves influenced by their business models and processes, and partly by wider market and regulatory factors. Ross (2000) surveyed around 200 social housing organisations and 100 builders/developers and also suggested that various policy and market drivers were leading to an increase in offsite manufacturing of dwellings. All these results are reflected in a recent crossindustry offsite market survey (Goodier and Gibb, 2004) which states that the use of offsite technologies bring benefits centred on shorter on-site duration and increased quality, but real or perceived additional cost comparing to traditional methods by clients and their advisors and long lead-in time act as the main barriers to use.

The preceding review of studies into the use of offsite technologies in housing has revealed a range of barriers to its take-up and various solutions. However, this extant body of work has not explored the perspectives of housebuilders per se. It is 
significant to contribute knowledge on the part of housebuilders with regard to the use of offsite-MMC given that the large firms account for the vast majority of housing developments and hence, are key to the wider take-up of offsite-MMC in the future. This research has explored how the benefits of such technologies could be harnessed to bring about change and improvement in housing supply. The present paper reports on a survey of the top 100 housebuilders which explores the large firms' views and recommendations in this regard.

\section{Methodology}

The survey of the top 100 housebuilders in the UK by volume (Wellings, 2003) was carried out through a combination of face-to-face and telephone interviews and a postal questionnaire survey. This approach yielded an overall response rate of $36 \%$ (Table 1). According to UK Government statistics, the number of housing unit completions in 2001/02 (UK) was 175,000, out of which private housebuilders contributed 153,500 (or $87 \%$ of the total). Based on statistics provided by the Private Housebuilding Annual 2003 (Wellings, 2003), the top 100 housebuilders contributed 113,882 (65\%) to the total amount by the industry. Thus, on this basis, the companies agreeing to take part in the research together accounted for more than $30 \%$ to the total housing unit completions in 2004/5. All of the interviews were carried out with senior managers with responsibility for company policy level decisions on whether to use offsite-MMC within their developments.

(Insert Table 1) 
An initial survey instrument was developed through a comprehensive literature review of the studies which had investigated the use of offsite-MMC in the past (e.g. Venables et al., 2004; Goodier and Gibb, 2004; Lusby-Taylor et al., 2004; Edge et al., 2002). The instrument comprised a mix of qualitative and quantitative questions with a methodical use of Likert scales (see Oppenheim, 1992) as well as other closeended questions. Section 1 aimed to provide overall views of housebuilders on offsite-MMC applications. Section 2 sought to identify the drivers and barriers and their importance or significance. Section 3 diagnosed the top 100 housebuilders' recommendations for the industry to increase the take-up of offsite-MMC. The instrument was refined through discussions with leading researchers and industrial contacts. The interviews lasted between one and two hours and significantly add rich data to the questionnaire survey of the firms. The data collected was analysed using a combination of Microsoft Excel and QSR NVivo.

\section{Results}

The findings of the survey are presented under headings derived from the research instrument. Whilst the sample size precludes the use of sophisticated statistical techniques, it does enable a broad picture of housebuilders' views on the current use of offsite-MMC, and recommendations for an increased take-up of offsite-MMC in the future, to be discerned through descriptive statistics.

\section{Housebuilders' satisfaction with construction methods}

The housebuilders' satisfaction with the use of both offsite-MMC and traditional construction methods is provided in Figure 1. Results show that the housebuilders surveyed are generally satisfied with their own, in-house, traditional construction 
methods (82\% satisfied / very satisfied). They are also fairly satisfied with the performance of the overall industry in traditional building (59\% satisfied / very satisfied). However, a significant number of these top housebuilders are not satisfied with the performance of offsite-MMC, both within their own organisations (31\%) and in the overall industry (47\%). There is also a large number of respondents that had a neutral view on this question (41\% \& 44\%). These somewhat disappointing figures are discussed later in this paper.

(Insert Figure 1)

\section{The trend in the take-up of offsite-MMC applications}

Nearly two thirds (64\%) of the housebuilders indicated that the industry needs to increase the take-up of offsite-MMC applications, 21\% were not sure and only $15 \%$ believed that no increase was necessary. The larger housebuilders were generally more favourable to increasing the take-up. Kitchen and bathrooms were seen as the best opportunity for growth in offsite solutions (44\%), with external walls (41\%), timber frame structures (37\%) and roofs (33\%) also featuring strongly. However, the housebuilders did not generally see great potential for complete modular buildings. The analysis of comments revealed that housebuilders assessed the potential for offsite-MMC applications against a wide range of factors including technical requirements, cost, time, site integration, customers' choices, sales, mortgage issues and site specific considerations. Comparison between responses from the largest and smaller firms showed that external walls and roofs are more prospected by largest firms, whilst there is no substantial difference of preferences over the other building elements. 


\section{Drivers for using offsite-MMC}

Respondents were asked to choose three most important drivers from a list derived from previous research. Figure 2 shows the frequency of responses expressed as a percentage of the sample. For the use of offsite-MMC in the industry the most important drivers were considered to be in addressing traditional construction skills shortages (61\%), ensuring time and cost certainty (54\%), achieving high quality (50\%) and then minimising on-site duration (43\%) (Figure 2). Reducing health and safety risks, sustainability issues, government promotion, complying with building regulations, restricted site specifics were also highlighted, but less frequently (less than $15 \%)$.

(Insert Figure 2)

\section{Barriers against the use of offsite-MMC}

Respondents were asked to choose three most significant barriers from a list derived from previous research. Figure 3 shows the frequency of responses expressed as a percentage of the sample. The significant barriers against the use of offsite-MMC in the industry were considered to be higher capital cost (68\%), difficult to achieve economies of scale (43\%), complex interfacing between systems (29\%), unable to freeze the design early on (29\%) and the nature of the UK planning system (25\%) (Figure 3). The risk averse culture, attitudinal barriers, fragmented industry structure, manufacturing capacity were suggested, but by a lower percentage of housebuilders (less than 15\%). The concerns of mortgage lenders and insurers with non-traditional buildings were also raised by a few respondents. 
(Insert Figure 3)

\section{Recommendations for increasing the take-up of offsite-MMC in the industry}

The respondents' ideas for promoting the take-up of offsite-MMC in the industry were explored via open questions from which a few recommendations were derived. The responses indicated that there exist significant prejudice against the take-up of offsite-MMC among housebuilders and the wider context of housing supply. Smaller housebuilders were even more reluctant than larger organisations. Peoples' perceptions should be challenged.

Many housebuilders said that partnering has not been fully understood by the industry. Cooperation between housebuilders and manufacturers and suppliers was weak in many cases. Improving procurement is key to achieving long-term success. Perceived higher capital cost was identified as the most significant barrier against the use of offsite-MMC. Better cost data and more transparent competitive costing are required. Many housebuilders indicated that the use of offsite-MMC appears more applicable for particular building types and / or house elements. Guidance on the decision-making process and practical applications should help increase the take-up of offsite-MMC.

The responses revealed that the slow process of obtaining planning permission and changing building regulations are inhibiting the use of offsite-MMC. It was claimed that many of the potential benefits from the use of offsite-MMC were not realised due to the delayed planning process. Planning needs to be more flexible and changing building regulations must be acknowledged. A significant number of 
respondents suggested that the government should subsidise the use of offsite-MMC to make them cost effective.

Strategies for implementing the recommendations were also provided by the responding firms. Both the recommendations and strategies are given in Table 2.

(Insert Table 2)

Improving skills and addressing concerns of the financial market and insurance industry were also raised but no detailed information was provided. Most of the responding firms argued that the implementation of the strategies require commitments from the whole supply chain covering housebuilders, designers, manufacturers and suppliers, institutions and the government.

\section{Discussion}

Survey results revealed that housebuilders are substantially more satisfied with the application of traditional construction methods than of offsite-MMC. These figures illustrate the inertia within major housebuilders against the uptake of offsite-MMC. Also, housebuilders appear to be much less satisfied with current offsite-MMC performance in their own industry than other sectors, for example building services as shown by a recent BSRIA study (Parry et al., 2003) with around 72\% satisfaction. Some may argue that housebuilders are hard to please, but this finding does not necessarily suggest housebuilders do not believe that there are considerable potential benefits from using offsite-MMC. Instead, the current low level of satisfaction with offsite-MMC application may be largely attributable to the low level of application 
of such technologies (Pan et al., 2006) with builders, not surprisingly, being supportive of their preferred work methods. Furthermore, because most of the respondents had actually made very little use of offsite techniques themselves, their answers may be biased by external influences \& perspectives. There is also evidence of a critical lack of knowledge on the use and benefits of offsite-MMC. This may also support the view that construction companies are typically risk averse and do not include many innovators or early-adopters (Moore, 2002; Rogers, 2003), preferring to allow others to take the risk of developing new products before they adopt them for themselves.

Other than housebuilders, the end-market has shown little interest in how housing is built. Research found that location and price are the two main determinants of which house to buy. Size and appearance are important, but design-based issues, such as layout, and technological considerations, such as maintenance, construction, insulation etc. are of more marginal importance (Edge et al., 2002). Within the context of the current critical shortage of housing supply, it can be argued that the measurement of attitudes should focus on the large housebuilders who account for the vast majority of housing completions and thus are determinant in increasing the take-up of offsite technologies.

Regarding the trend in the take-up of offsite-MMC, this paper has shown that nearly two thirds of the housebuilders believe that the industry needs to increase the take-up of such technologies, which reflects the findings of some recent studies. Hooper and Nicol (2000) also identified that many large housebuilders believed that significant technological change would impact upon the industry in the future. Goodier and 
Gibb (2004) found that nearly three quarters of the suppliers surveyed thought that the take-up of offsite techniques by industry was increasing in their sector. Parry et al. (2003) predicted a growth in the offsite fabrication market of 9.7\% per annum (by value) up to 2010. AMA (2002) indicated that the market value of prefabricated buildings at manufacturers selling price will grow at an average rate $8 \%$ per year between 2001 and 2006. From 2004, the Housing Corporation started to require a quarter of new houses it funds to be built using MMC, equivalent to approximately 5,000 homes per year, or 3\% of new UK housing (POST, 2003). Despite some inconsistency in the actual figures, all these sources show a promising prospect of using offsite-MMC in the housebuilding sector. This should all be viewed in the context of the UK industry body, Buildoffsite's aspirational ten-fold growth in offsite across all construction sectors by 2020 (Buildoffsite, 2005). However, it is interesting to note, according to the responses, that the increase potential largely exists within the areas of kitchen and bathrooms, external walls, timber frame structures and roofs. Some highly documented offsite techniques like complete modular building were not identified for growth..

The results on drivers and barriers support a number of recent studies. Time and quality drivers identified in this paper have also been highlighted in the studies of Gibb and Isack (2003), Goodier and Gibb (2004), Venables et al. (2004) and Parry et al. (2003). In terms of the driver of ensuring cost certainty, Lusby-Taylor et al. (2004) believed that costs should be less volatile than in traditional construction although it is unlikely at present that costs will be reduced by the use of MMC. However, they also suggested that cost uncertainty on volumetric and closed panel systems is inhibiting designers from exploring the full potential of these systems. The driver of 
addressing skills shortages has been recognised (ODPM, 2003; Barker, 2003). However, a skilled workforce is still needed for offsite technologies and better, broader training and career encouragement must be taken on board (Goodier and Gibb, 2004; Venables et al., 2004; Clarke, 2002; Palmer et al., 2003). These arguments explain that the issue of skills shortages, particularly factory-based skills, was also indicated as a significant barrier by a number of housebuilders. Taken together, the findings of all of these studies suggest that the traditional drivers of time, cost, quality and productivity are still encouraging the industry to make more use offsite technologies. Factors such as health and safety, sustainability and clients' influences appear to be of more marginal importance. For the barriers, Goodier and Gibb (2004) similarly concluded that the belief that offsite is more expensive when compared with traditional construction is clearly the main barrier to its increased use. The longer lead-in time was also identified as a significant barrier, particularly from a contractor's perspective. This mirrors the findings in Venables et al. (2004) which suggested long lead-in time as the most significant disadvantage, followed by matching tolerances to onsite work, public and industry perception and cost.

Housebuilders' recommendations identified in this paper for increasing the take-up of offsite-MMC in the industry generally corroborate the suggestions existing in the literature. The suggestion of changing peoples’ perceptions reflects the work of Ross (2000) and the Housing Forum (2002), which suggested that commitment was required from the whole supply chain. The current Barker Recommendation 33 study (Barker 33 Cross Industry Group, 2006) also asserts that gathering together all the stakeholders is vital to realise the successful introduction of a process like MMC. Discussions with the housebuilders suggested a wide range of stakeholders who have 
interest and influence on the use of offsite-MMC either directly or indirectly. These stakeholders identified were clustered using a value tree method into four groups at the generic level which were further broken down onto industry and organisational levels (Figure 4). The model maps out, from housebuilders' points of view, the internal and external stakeholders, targeting the end market, within the statutory and regulatory framework. The many stakeholders must be fully recognised and engaged for the benefits of offsite-MMC to be realised.

(Insert Figure 4)

Stakeholder analysis (Newcombe, 2003) and stakeholder mapping (Johnson et al., 2005) have been regarded as important means to identify stakeholders’ interests and influences in project delivery. The same approach could be applied to practices involving offsite production. Considering the requirement of early integration of manufacturers and suppliers and long lead-in time for the use of offsite-MMC, an ideal stakeholder model should also include timescale. However, establishing which stakeholders should be involved at each stage of the process would require further research.

The suggestion of improving procurement has also been proposed by Venables et al. (2004) and Goodier and Gibb (2004). Effective ways of bringing specialist knowledge holders into the design process at an earlier stage should be established (ibid; Palmer et al., 2003). However, the strong reliance on subcontracting in UK construction projects (Clarke and Herrmann, 2004; Dainty et al., 2001) creates problems for using innovative building techniques (Ball, 1996). Housebuilders' 
comments reflect the observation in (Hong-Minh et al., 2001) that current housing supply chains are fragmented and underpinned by poor communication, adversarial relationships and a lack of trust and commitment. Partnering has been promoted to address the fragmented supply chain. However, the perceptions of housebuilders, coupled with the high demand for housing, limited supply and the lack of product competition are inhibiting the progress towards partnering and greater customer focus (Naim and Barlow, 2003). Relationships are still characterised by a cost-driven agenda (Wood and Ellis, 2005). A ‘leagile’ approach (combining ‘lean’ and 'agile’ production see Naim and Barlow, 2003) to housebuilding has been proposed to achieve both the minimisation of resources requirements through the elimination of waste in the supply chain and the maximisation of customer service at an acceptable cost. Hong-Minh et al. (2001) suggested housebuilding companies should change the "mind-set", to become process-orientated and to improve communication and learning. It is clear from all this work that improving procurement is key to the longterm success of the industry.

As to the cost of offsite-MMC, housebuilders believed that this was a major cause in preventing the industry from a greater take-up of such technologies. The same suggestion was made by Goodier and Gibb (2004) and Venables et al. (2004). Moreover, this survey also suggests that more transparent, comparative costing methods should be applied to housing to be built by offsite-MMC. The use of elemental cost analysis by considering the building elements in isolation is unlikely to deliver a balanced cost comparison but rather cause neglect of many other benefits in the construction process (Gibb, 2001). It has also been argued that, given the fact that many manufacturers and suppliers seek the maximum price that the market will 
sustain, the tender prices quoted may not reflect the actual costs. This hinders sensible comparisons with conventional construction (ibid). Furthermore, supposed economies of scale from the factory production are actually rarely realised since the manufacturers have to wait on orders via the general contractors (Groak, 1992). The findings on cost associated with the literature open a considerable scope of work on providing better cost data using balanced transparent comparative costing methods.

The recommendations targeting the government and government agencies on planning, support the current movements toward a more flexible and marketresponsive planning system (DETR, 2000; ODPM 2003; Barker, 2004; ODPM, 2005b). However, research in the 2005 Housing Market Intelligence report (see Housebuilder, 2005) reveals that the government's movements have not led to an improvement in the planning process. Planning authorities are now far quicker to process applications. This demands that developers resubmit projects that have been rejected for planning permission rather than enter negotiations. This approach is shortening decision times on which authorities are targeted but there is little evidence to suggest that it is reducing the time taken to get applications through the planning process (ibid). The strategy of local authority gearing is also seen in Barlow et al., (2002) which suggested reforming planning practices within local authorities.

The survey reveals a critical shortage of knowledge on the decision-making process and site integration of offsite-MMC in the housebuilding sector. Most of the studies reviewed lack justified statistical analysis and exploration of the management and decision-making processes associated with the use of offsite construction. This finding supports the argument by Roy et al. (2005) that there is a lack of standards, 
and of mechanisms for process review or sharing knowledge and good practice which result in significant process variability on site. Nevertheless, a few toolkits exist which use offsite technologies within the context of general construction. However, further work is needed to transfer this knowledge for use in housebuilding. There are also various toolkits, systems and patents developed by firms and individuals relating to the use of innovative building technologies but are not publicly accessible due to business reasons. A thorough review of these toolkits, patents and systems should help disseminate industry's knowledge on the use of offsite technologies.

All the suggestions provided by the housebuilders can be seen as being mutually supportive. Together, they present a framework of strategies for the industry to increase the take-up of offsite-MMC. Improving procurement, providing better cost and providing guidance should function as the means, tackling planning and encouraging political levers being the guarantee, and changing peoples’ perceptions serves as a premise for implementing all the strategies.

\section{Conclusions and future research}

There is a case for the use of offsite technologies in addressing the current housing under-supply and improving performance. Against the backdrop of limited take-up in offsite technologies however, this paper has reviewed housebuilders' perspectives of the industry's use of offsite-MMC through a survey of the top 100 firms. The study has suggested that the traditional drivers of time, cost, quality and productivity are still strong influencers for the industry in deciding whether to use offsite technologies. Factors such as health and safety, sustainability and clients’ influences 
appear to be of more marginal importance. Nearly two thirds of the housebuilders believed that there needs to be an increase in the take-up of offsite technologies in the housing sector. However, current barriers to the offsite utilisation relate to a perceived higher capital cost, the difficulty to achieve economies of scale, complex interfacing between systems, the inability to freeze the design early on and the nature of the UK planning system. Strategies recommended for encouraging the utilisation of offsite technologies centred on changing peoples' perceptions, improving procurement, providing better cost data, tackling planning and regulations, encouraging political levers and providing guidance on the decision-making process and site integration of offsite-MMC.

The findings of this study have emphasised the importance of engaging all the industry players in delivering housing supply in both quantity and quality. This paper has provided to the construction community a framework of strategies for encouraging the take-up of offsite technologies in the housing sector. All the strategies are interrelated and require commitments from government and the industry but changing peoples' perceptions is fundamental. The paper is limited to investigating housebuilders' perspectives using questionnaire survey and personal interviews. This left the wider organisational context of the companies less explored. The practices of housebuilders in their ethnographical context are addressed in a parallel paper. Future research will explore the implementation of the strategies provided. Particular attention will be paid to investigating the decision-making process on the use of offsite technologies and transferring knowledge to housebuilding from the general construction. 


\section{References}

AMA (2002) The UK Prefabricated Buildings Market Report 2002, AMA Research, Cheltenham.

Ball, M. (1996) Housing and Construction: A troubled relationship?, The Policy Press, Bristol.

Ball, M. (1999) Chasing a Snail: Innovation and Housebuilding Firm's Strategies. Housing Studies, 14(1), 9-22.

Barker 33 Cross Industry Group (2006) Modern Methods of Construction (MMC) for the Provision of Housing: Barker 33 Review - Recommendations, Barker 33 Cross Industry Group, London.

Barker, K. (2003) Review of Housing Supply: Securing our Future Housing Needs, Interim Report - Analysis, HMSO, London.

Barker, K. (2004) Review of Housing Supply: Final Report - Recommendations, HMSO, London.

Barlow, J. (1999) From Craft Production to Mass Customisation. Innovation Requirements for the UK Housebuilding Industry. Housing Studies, 14(1), 23-42.

Barlow, J., Bartlett, K., Whitehead, C. and Hooper, A. J. (2002) Land for Housing: Current Practice and Future Options, Joseph Rowntree Foundation, York.

BRE Certification (2005) Standard for Innovative Methods of Dwelling Construction LPS 2020:2005, Issue: Version 3, BRE Certification, Watford.

Buildoffsite (2005) buildoffsite: promoting construction offsite. Available from www.buildoffsite.com .

Clarke, L. (2002) Standardisation and skills: a transnational study of skills, education and training for prefabrication in housing, University of Westminster Business School, London.

Clarke, L. and Herrmann, G. (2004) Cost vs. production: disparities in social housing construction in Britain and Germany. Construction Management and Economics, 22(June), 521-32.

Dainty, A. R. J., Briscoe, G. H. and Millett, S. J. (2001) Subcontractor perspectives on supply chain alliances. Construction Management and Economics, 19, 841-8.

DETR (2000) Quality and Choice: A Decent Home for All - The Housing Green Paper, Department of the Environment, Transport and the Regions, London. 
Edge, M., Craig, A., Laing, R., Abbott, L., Hargreaves, A., Scott, J. and Scott, S. (2002) Overcoming Client and Market Resistance to Prefabrication and Standardisation in Housing, Robert Gordon University, Aberdeen.

Egan, J. (1998) Rethinking Construction: The Report of the Construction Task Force, Department of the Environments, Transport and the Regions, London.

Gibb, A. G. F. (1999) Off-site Fabrication: Prefabrication, Pre-assembly and Modularisation. Whittles Publishing, Caithness.

Gibb, A. G. F. (2001) Standardisation and Pre-assembly - distinguishing myth from reality using case study research. Construction Management and Economics, 19(3), 307-15.

Gibb, A. G. F. and Isack, F. (2003) Re-engineering through pre-assembly: client expectations and drivers. Building Research \& Information, 31(2), 146-60.

Goodier, C. and Gibb, A. (2004) Barriers and opportunities for Off-site Production, Loughborough University, Loughborough, prOSPa WP4.

Goodier, C. and Gibb, A. (2005) The value of the UK market for offsite, Buildoffsite: promoting construction offsite, www.buildoffsite.co.uk.

Groak, S. (1992) The Idea of Building: Thought and action in the design and production of buildings. E \& FN Spon, London.

Hong-Minh, S. M., Barker, R. and Naim, M. M. (2001) Identifying supply chain solutions in the UK house building sector. European Journal of Purchasing \& Supply Management, 7, 49-59.

Hooper, A. J. (1998) Standardisation, Innovation and the Housebuilding Industry, in Harlow, P. (eds) Construction Papers, 95. CIOB, Ascot.

Hooper, A. J. and Nicol, C. (2000) Design practice and volume production in speculative housebuilding. Construction Management and Economics, 18, 295310.

Housebuilder (2005) ODPM planning targets lead to "reject and resubmit" cycle". Housebuilders, September, 3.

Housing Forum (2001) Enemies of Promise, The Housing Forum, London.

Housing Forum (2002) Homing in on excellence: A commentary on the use of off-site fabrication methods for the UK housebuilding industry, The Housing Forum, London.

Johnson, G., Scholes, K. and Whittington, R. (2005) Exploring Corporate Strategy, 7th Edn. Pearson Education Ltd, Harlow. 
Latham, M. (1994) Constructing the Team. Final report of the government/industry review of procurement and contractual arrangements in the UK construction industry, HMSO, London.

Lusby-Taylor, P., Morrison, S., Ainger, C. and Ogden, R. (2004) Design and Modern Methods of Construction, The Commission for Architecture and the Built Environment (CABE), London.

Moore, G. A. (2002) Crossing the Chasm: Marketing and selling high-tech products to mainstream customers, Revised Edn, HarperCollins Publishers, New York.

Naim, M. and Barlow, J. (2003) An innovative supply chain strategy for customised housing. Construction Management and Economics, 21(September), 593-602.

Newcombe, R. (2003) From client to project stakeholders: a stakeholder mapping approach. Construction Management and Economics, 21(December), 841-8.

ODPM (2003) Sustainable Communities: Building for the Future, Office of the Deputy Prime Minister, London.

ODPM (2005a) Sustainable Communities: Homes for All, ODPM, London.

ODPM (2005b) Planning for Housing Provision: Consultation Paper, ODPM, London.

Oppenheim, A. N. (1992) Questionnaire Design, Interviewing and Attitude Measurement, New Edn. Continuum, London.

Palmer, S., Jones, K., Coffey, M. and Blundell, C. (2003) Innovation in Construction: Maintenance and the Egan Agenda, The Palmer Partnership, Dartford.

Pan, W., Dainty, A. R. J. and Gibb, A. G. F. (2004) Encouraging Appropriate Use of Off-site Production (OSP): Perspectives of Designers, In 2nd CIB Student Chapter International Symposium, 30-31 Oct 2004, Beijing, China. The Hong Kong Polytechnic University, 125-36.

Pan, W., Gibb, A. F. G. and Dainty, A. R. J. (2006) The Utilisation of Offsite Modern Methods of Construction by Leading Housebuilders. Building Research and Information, In Press.

Parry, T., Howlett, C. and Samuelsson-Brown, G. (2003) Off Site Fabrication: UK Attitudes and Potential, BSRIA, Report 17356/1.

POST (2003) Modern Methods of Housing Building, Postnote Number 209. The Parliamentary Office of Science and Technology (POST), London.

Rogers, E. M. (2003) Diffusion of Innovations, 5th Edn. The Free Press, New York.

Roskrow, B. (2004) Design and deliver. Housebuilder, September, 18-20. 
Ross, K. (2000) DETR Construction Directorate Project Report: Advanced off-site production of steel/timber building systems: Report on Market Survey, Project Report Number 80-680 (Unpublished). BRE, Gaston, Watford.

Roy, R., Low, M. and Waller, J. (2005) Documentation, standardisation and improvement of the construction process in house building. Construction Management and Economics, 23(January), 57-67.

Sparksman, G., Groak, S., Gibb, A. and Neale, R. (1999) Standardisation and Preassembly: Adding Value to Construction Projects, CIRIA, London.

Venables, T., Barlow, J. and Gann, D. (2004) Manufacturing Excellence: UK Capacity in Offsite Manufacturing, The Housing Forum, London.

Wellings, F. (2003) Private Housebuilding Annual 2003, The Builder Group, London.

Wood, G. D. and Ellis, R. C. T. (2005) Main contractor experiences of partnering relationships on UK construction projects. Construction Management and Economics, 23(March), 317-25. 
Tables (in the sequence referred in the paper):

\begin{tabular}{|c|c|c|c|c|}
\hline Housebuilders & $\begin{array}{c}\text { Unit } \\
\text { completions }\end{array}$ & $\begin{array}{l}\text { Turnover } \\
\text { (£m) }\end{array}$ & Interview & $\begin{array}{c}\text { Questionnaire } \\
\text { survey }\end{array}$ \\
\hline A1 & 13480 & 2062 & & $\sqrt{ }$ \\
\hline A2 & 6238 & 1184 & & $\sqrt{ }$ \\
\hline A3 & 6044 & 773 & $\sqrt{ }$ & $\sqrt{ }$ \\
\hline A4 & 4164 & 827 & $\sqrt{ }$ & $\sqrt{ }$ \\
\hline A5 & 3812 & 560 & $\sqrt{ }$ & $\sqrt{ }$ \\
\hline A6 & 2691 & 461 & $\sqrt{ }$ & $\sqrt{ }$ \\
\hline A7 & 1901 & 224 & $\sqrt{ }$ & $\sqrt{ }$ \\
\hline A8 & 1854 & 456 & $\sqrt{ }$ & $\sqrt{ }$ \\
\hline A9 & 1387 & 203 & & $\sqrt{ }$ \\
\hline A10 * & 1307 & 231 & $\sqrt{ }$ & $\sqrt{ }$ \\
\hline $\bar{B} 1$ & 1085 & 233 & $\sqrt{ }$ & $\sqrt{ }$ \\
\hline B2 & 1075 & 102 & & $\sqrt{ }$ \\
\hline B3 & 877 & 145.6 & & $\sqrt{ }$ \\
\hline B4 & 775 & 82.4 & $\sqrt{ }$ & $\sqrt{ }$ \\
\hline B5 * & 694 & 88.7 & $\sqrt{ }$ & $\sqrt{ }$ \\
\hline B6 & 621 & 82.7 & $\sqrt{ }$ & $\sqrt{ }$ \\
\hline B7 & 582 & 39.5 & & $\sqrt{ }$ \\
\hline B8 & 504 & 101.6 & & $\sqrt{ }$ \\
\hline B9 & 478 & 51.3 & & $\sqrt{ }$ \\
\hline C1 & 445 & 46.5 & & $\sqrt{ }$ \\
\hline C2 & 331 & 42.4 & & $\sqrt{ }$ \\
\hline C3 & 257 & 24.7 & & $\sqrt{ }$ \\
\hline $\mathrm{C} 4$ & 240 & 64.7 & & $\sqrt{ }$ \\
\hline C5 & 204 & 23.2 & & $\sqrt{ }$ \\
\hline C6 & 174 & 24.7 & & $\sqrt{ }$ \\
\hline C7 & 173 & 17.6 & & $\sqrt{ }$ \\
\hline C8 & 150 & 50.3 & & $\sqrt{ }$ \\
\hline C9 & 150 & 18.8 & & $\sqrt{ }$ \\
\hline C10 & 150 & 51.1 & & $\sqrt{ }$ \\
\hline C11 & 149 & 24.9 & & $\sqrt{ }$ \\
\hline $\mathrm{C} 12$ & 124 & 12.1 & & $\sqrt{ }$ \\
\hline $\begin{array}{l}\text { Total of respondent } \\
\text { firms }\end{array}$ & $52,116+$ & $8308.8+$ & 11 & 36 \\
\hline The industry as a whole & 175,600 & & & \\
\hline Percentage & $30 \%+$ & & & \\
\hline
\end{tabular}

Table 1 Details of responding housebuilders

Source: The Private Housebuilding Annual 2003 (Wellings, 2003).

Notes: 1) 'A' stands for housebuilders from the group of top 20; ' $B$ ' from top 21-40; and ' $C$ ' from top 41-100. 2) The housebuilders with * have been acquired by others. $3)$ ' + ' means that some respondent firms are anonymous and thus their details are not included in this table. 


\begin{tabular}{|c|c|}
\hline Recommendations & Implementation strategies \\
\hline Changing peoples’ & $\begin{array}{l}\text { - Test and demonstrate that offsite-MMC can deliver as good or better } \\
\text { performance than traditional methods }\end{array}$ \\
\hline perceptions & $\begin{array}{l}\text { - Provide a UK central site with practical offsite-MMC examples } \\
\text { - Develop a consistent and objective approach to the use of offsite } \\
\text { techniques among institutes }\end{array}$ \\
\hline Improving procurement & $\begin{array}{l}\text { - Form Strategic Partnering Alliances (SPA). } \\
\text { - Integrate manufacturers \& suppliers in the project decision-making } \\
\text { process as early as possible } \\
\text { - Improve cooperation between all parties }\end{array}$ \\
\hline Providing better cost data & $\begin{array}{l}\text { - Provide better cost data to facilitate more competitive costing } \\
\text { - Embrace the approach 'value for money' rather than 'lowest first } \\
\text { cost focus' } \\
\text { - Increase design standardisation and address the issue of economies } \\
\text { of scale. }\end{array}$ \\
\hline Tackling planning and & $\begin{array}{l}\text { - Make the planning system more flexible and market responsive } \\
\text { - Establish dialogues between housebuilders and local authorities }\end{array}$ \\
\hline building regulations & $\begin{array}{l}\text { - Housebuilders should keep compliance with enhanced building } \\
\text { regulations } \\
\text { - Designers should not sacrifice design flexibility when specifying the } \\
\text { use of offsite-MMC. }\end{array}$ \\
\hline Encouraging political & $\begin{array}{l}\text { - It was suggested that the Government award tax deductions for } \\
\text { projects involving the use of offsite-MMC to permit the cost of the }\end{array}$ \\
\hline levers & $\begin{array}{l}\text { 'learning curve' in housebuilding organisations to be recovered. } \\
\text { should be reasonably restricted to provide a more favourable context } \\
\text { for the use of offsite-MMC. }\end{array}$ \\
\hline \multicolumn{2}{|l|}{ Providing guidance on the } \\
\hline use of offsite-MMC & $\begin{array}{l}\text { - Provide guidance on project decision-making process } \\
\text { - Provide guidance on the site integration of offsite-MMC }\end{array}$ \\
\hline
\end{tabular}

Table 2 Housebuilders’ recommendations \& implementation strategies 
Figures (in the sequence referred in the paper):

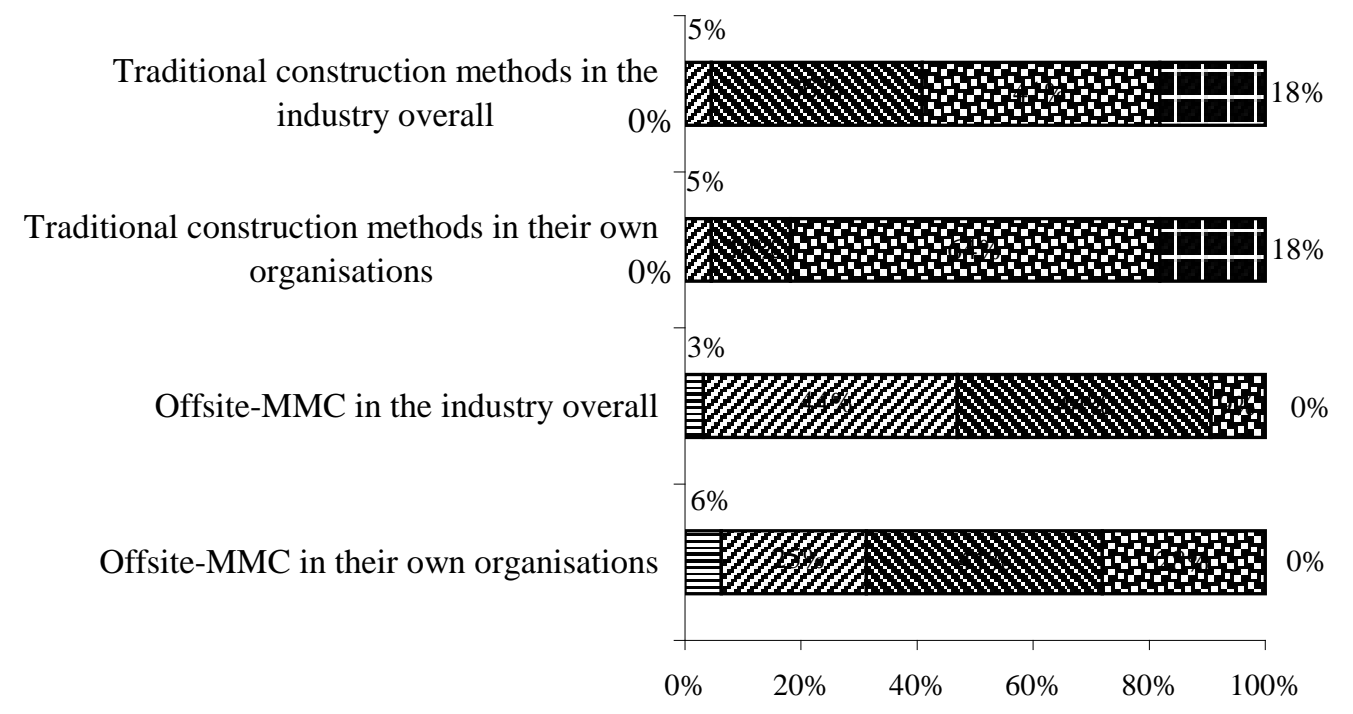

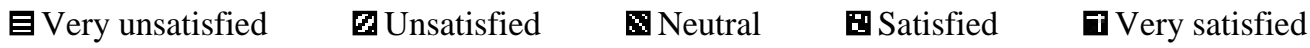

Figure 1 Housebuilders' satisfaction with the use of both offsite-MMC and traditional construction methods 


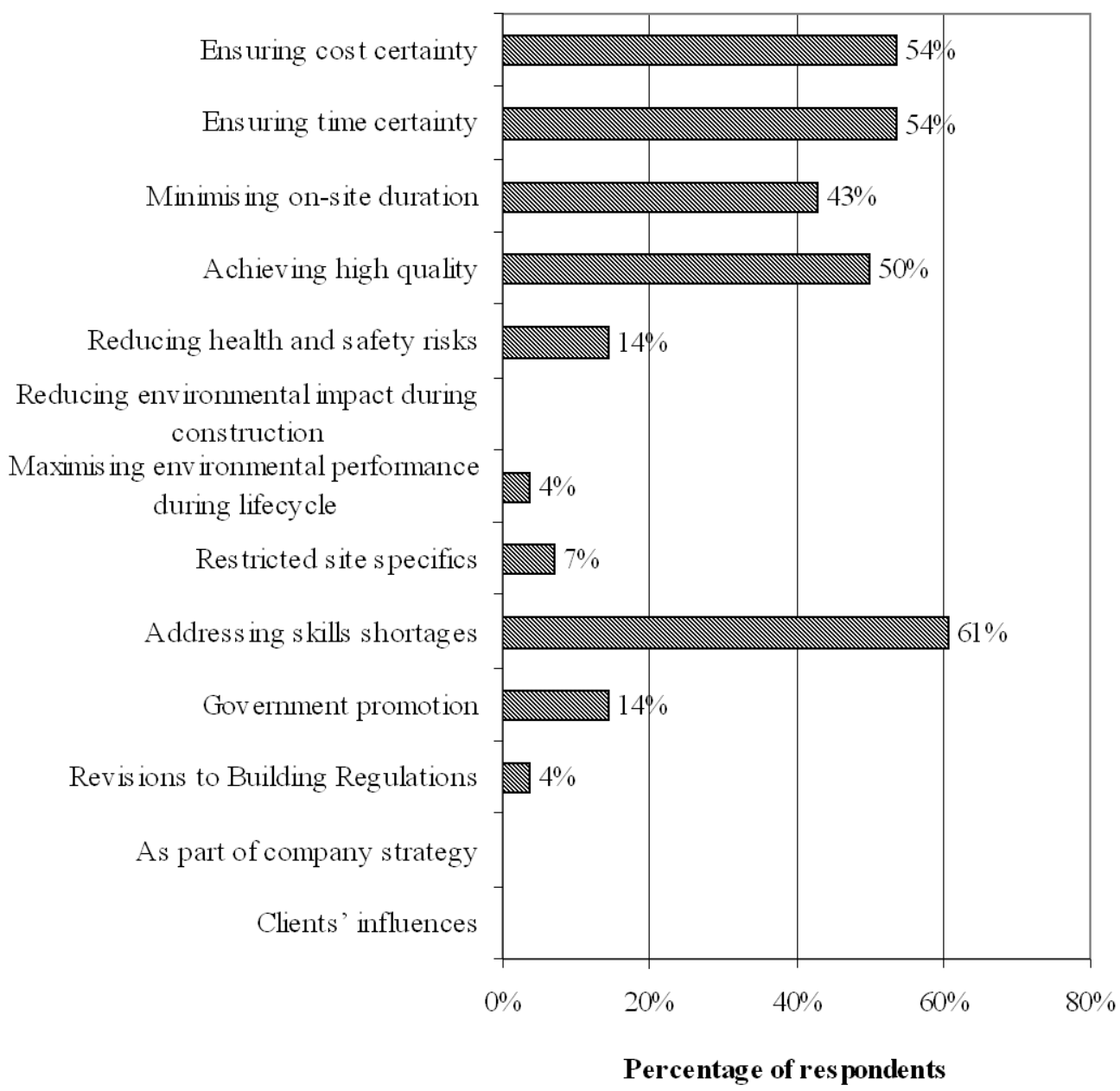

Figure 2 Most important drivers for using offsite-MMC in the industry 


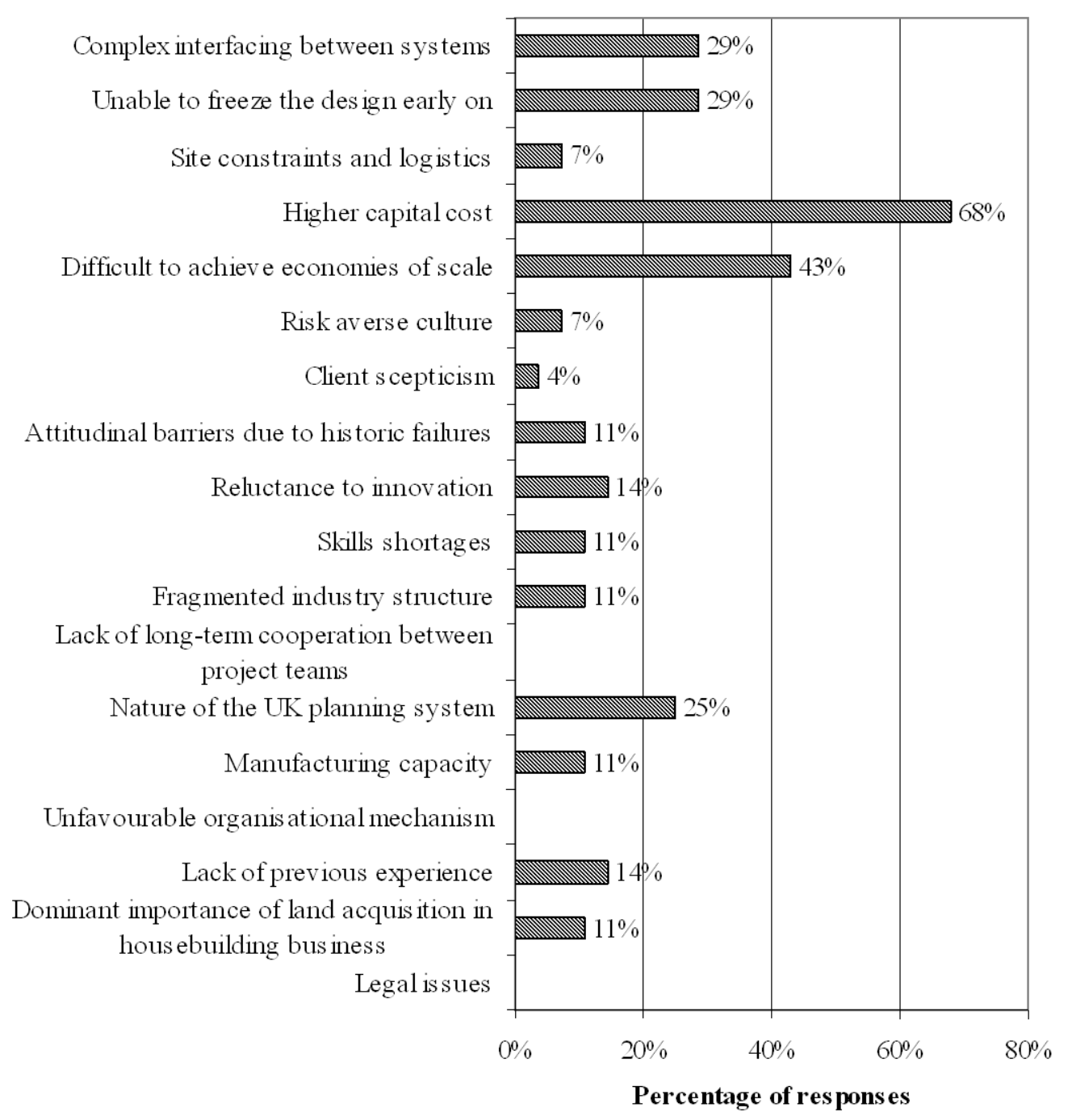

Figure 3 Most significant barriers against the use of offsite-MMC in the industry 


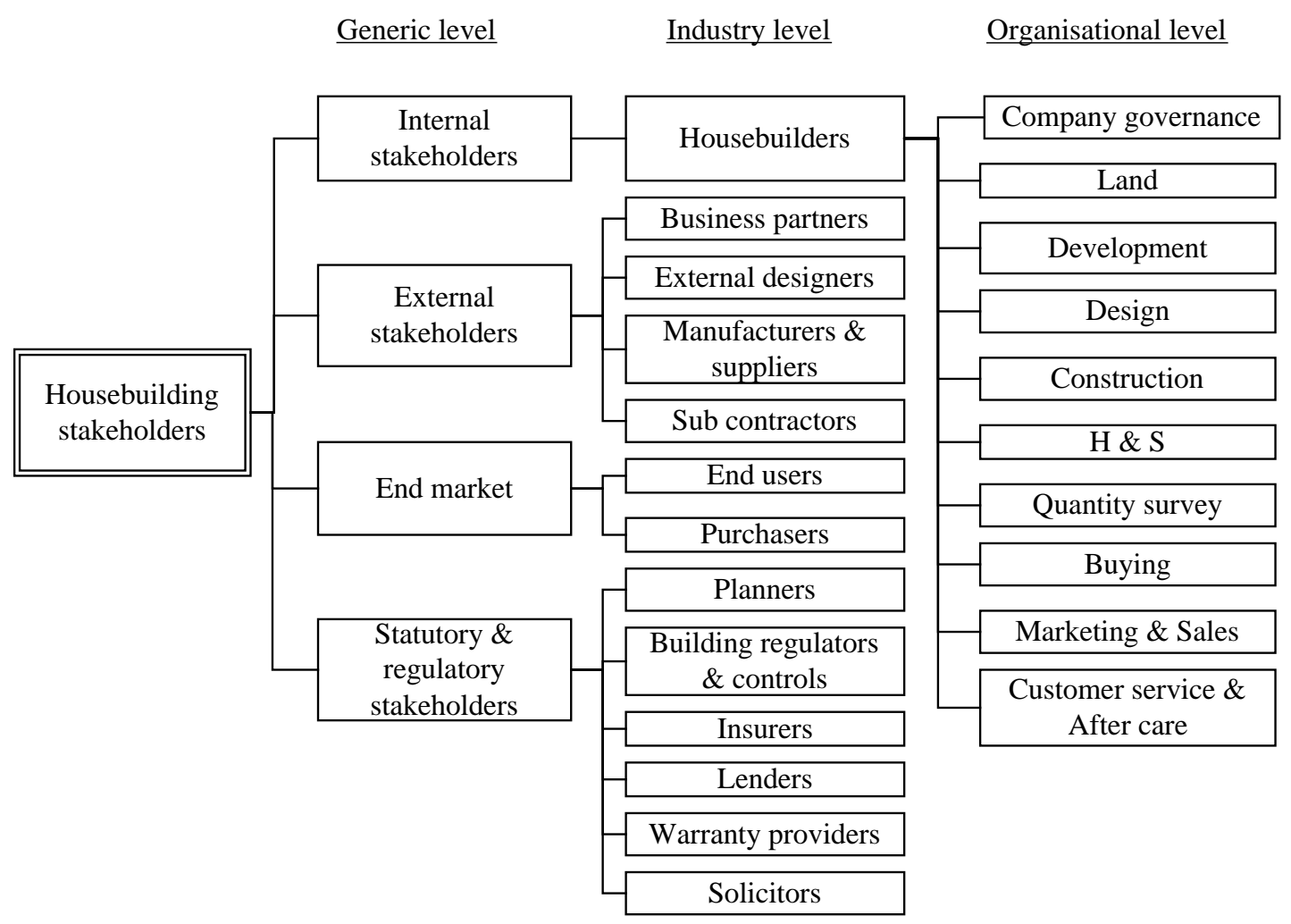

Figure 4 Model of housebuilding stakeholders from the perspective of housebuilders 